\title{
Adoption of Improved Rice Varieties among Small- Scale Farmers in Katcha Local Government Area of Niger State, Nigeria
}

Jirgi, A. J, Abdulrahman - M. and Ibrahim F. D .

Department of Agricultural Economics and Extension Technology, Federal University of Technology

P.M.B 65, Minna, Niger State, Nigeria.

E-mail: abijirgijohn @ yohoo.com

\begin{abstract}
The study broadly aims at providing information on the adoption of improved rice varieties among small-scale farmers in Katcha Local Government Area of Niger state, Nigeria. The study was conducted in 2007 cropping season. Data were generated from a sample of 100 farmers using questionnaire. Results indicated a high rate of awareness of improved rice varieties. The main sources of information were radio and extension agents. The major reasons for nonadoption of improved rice varieties are that they are expensive and nonavailability of the input. The study recommends policies that would strengthen the existing media and extension services. Also, improved rice varieties and other input that could enhance farmers output be made available to the farmer at affordable prices.
\end{abstract}

\section{INTRODUCTION}

Rice (Oryza sativa) is a cereal which has become a staple food of considerable strategic importance in many rapidly growing African cities, where its consumption among urban and rural poor households has increased considerably (WARDA, 2003).

Rice is the second most important cereals in the world after wheat in terms of production (Jones,1995).Nigeria ranks the highest as both producer and consumer of rice in the West Africa Sub-region. However, in terms of area of land under food crop production in the Country, rice ranks sixth( after sorghum, millet, cowpea, cassava and yam) (Imolehin and Wada,2000.)

The average annual Rice production in Nigeria is dominated by small holder farmers who cultivate small hectares of land using traditional methods of farming; yields are low and hence the wide gap of demand and supply. The definition of a small farm is obviously based on the size of the farm holding. Small farms are usually defined as those smaller than the average farm size at a provincial or national level. However, farm size alone is not always a good criterion for categorizing farmers. Farmers who own 1 ha of irrigated land are generally more prosperous than those who own 2 ha of land in a drought prone area of low productivity. In most developing countries of Asia, the average land holding ranges from 1 to 2 ha (www.agnet.org/libraray/bc/44002).

In order to increase rice production in the country, the federal government has designed policies and programs aimed at boosting domestic production to meet domestic demand since 1989 (Idiong, 2005). These include amongst others, the Fadama Rice Programme, the Japanese 
Journal of Agricultural Extension

Vol. 13 (1) June, 2009

Assisted National Rice Production Project as well as the River Basin Development Rice Programme.

Various Research institutes have been established in the country in order to boost rice production, some of which are the National Cereals Research Institute (NCRI), Badeggi, and National Seed Service (NSS).Some of the improved rice varieties developed by National Cereal Research Institute Badeggi in conjunction with International Institute for Tropical Agriculture (IITA) Ibadan and West African Rice Development Association (WARDA) are FARO 44, FARO 45, FARO 46, FARO 47, FARO 48, FARO 50, FARO 51 and FARO 55 among others.

The development of these improved rice varieties are aimed at increasing food production as well as alleviate poverty. Despite all the efforts made by the government and research institutes rice production still remains very low. Research has shown that farmers have not adequately adopted improved rice varieties but rather they still depend largely on the local varieties which give low yield and thus low productivity. It is to this backdrop that the following research questions are asked.

What are the socio-economic characteristics of rice farmers in Katcha local government area? What is the awareness and adoption of improved rice varieties in the study area? What are the channels used for dissemination of new technologies to rice farmers? Is rice production profitable?

The aim of this study was to examine the awareness and adoption of improved rice varieties in the study area.

\section{METHODOLOGY Area of Study}

This study was carried out in Katcha Local Government Area (LGA) of Niger state. Niger state lies between latitude $8^{\circ} 21^{\prime}$ and $11030^{\prime} \mathrm{N}$ and longitudes $3^{\circ} 30$ 'and $7^{\circ} 20^{\prime} \mathrm{E}$. It is situated in the middle belt zone of Nigeria and is indispensably one of the largest fertile agricultural lands in Nigeria covering about $8,733,170 \mathrm{~km} 2$ of the total land area of the country. It is characterized with distinct wet and dry seasons. With a population of over 3 million (National Population Census, 2006), over $80 \%$ of this population engage directly or indirectly in agricultural activities. The major crops cultivated in the study area are; rice and guinea corn. While maize, millet and groundnut are produced as minor crops. Farmers in this area are mainly fishermen. Livestock farming is also practiced with sheep, goats, cattle and poultry reared mostly on free range.

\section{Data Collection}

A combination of purposive and simple random sampling techniques was employed for selection of respondents for the study. Five major rice producing villages were purposively selected from the local government area which are Katcha, Kasha, Ndayagi, Sabon Gari and Gbakeko.Twenty farmers from each of the five villages were selected using the random sampling procedure, making a total one hundred farmers. Data used for this study were primarily generated with the use of questionnaire and interview schedule administered on the respondents. The data were collected during the 2007 cropping season.

\section{Data Analysis}

Frequencies and percentages were used to achieve the first and second objectives, while farm budgeting technique was used to achieve the third objective. The budgeting tool was used to determine the Net Farm Income (NFI). Net Farm Income, according to Olayide and Heady (1982), Olukosi and Erahbor (1988) is expressed as NFI = TR-TC; where: 
$\mathrm{NFI}=$ Net Farm Income ( $\mathrm{A} / \mathrm{ha})$

$\mathrm{TR}=$ Total Revenue $(\mathrm{N} / \mathrm{ha})$

$\mathrm{TC}=$ Total Cost $(\mathbb{A}$ /ha)

$\mathrm{GM}=\mathrm{TR}-\mathrm{TVC}$; where:

$\mathrm{GM}=$ Gross Margin (A/ha)

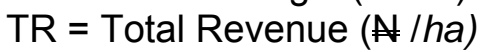

TV = Total Variable Cost $(\mathrm{N} / h \mathrm{~h})$.

The depreciation on value assets was determined using a straight line depreciation method.

\section{RESULTS AND DISCUSSION}

\section{The Socio-Economic Characteristics of The Respondents}

The socio-economic profile of respondents result from the study shows that a typical farmer sampled was male 39 years old, married with a household size of 11 people.

The average farm size was 1.5 hectares (Table 1 ).

TABLE 1: Socio-economic Characteristics of the Respondents

\section{Variables}

Male

Married

Average age (years)

Average household size(number)

Average farm size (ha)

\section{Awareness and Adoption}

Awareness is the first stage of technology adoption (Akanya, 1990; Adeniji 1996). A farmer has to know about new innovation before adopting it. Table 2 shows that majority (78\%) of the respondents are aware of improved rice varieties and have adopted it, while 22 percent of the respondents claimed to be ignorant about improved rice varieties. This is similar to the findings of Chinaka et al (2007) on adoption of improved agricultural technologies by farmers in Aba agricultural zone, Abia state. There is a gap between awareness and adoption of innovation. Adeniji (1996) observed that the use of recommended farm innovations by farmers was less than the knowledge of innovation. Similar results were reported by Adeniji (2007).

TABLE 2: Respondents Level of Awareness and Adoption of Improved Rice Varieties

\begin{tabular}{lllll}
\hline Improved rice production & Aware\% & Not aware\% & Adopted\% & Not adopted\% \\
\hline Improved rice varieties & 78 & 22 & 71.79 & 28.21 \\
\hline
\end{tabular}


Journal of Agricultural Extension

Vol. 13 (1) June, 2009

\section{Sources of Information on Improved Rice Varieties}

The sources of information through which the respondent first heard about improved rice verities includes Radio, Extension agents, Television and Pamphlets. Table 3 shows the various sources of information to farmer on improved rice varieties. It shows that $56 \%$ of the farmers received information through the radio. Twenty eight percent $(28 \%)$ identified extension agents as the main sources of information. Other sources identified were television indicated by $10 \%$ of the respondents while $6 \%$ identified pamphlets as the major source. This finding is contrary to the study on adoption of improved cotton production technologies in Katsina State, Nigeria by Adeniji, (2007) which showed that the extension agents were the major channel through which farmers receive information on improved practices. The high response to radio, was popular because most farmers have radio or were able to listen to farming programs. Radio is equally one of the fastest means of communicating with generality of farmers. This disagrees with the findings of Voh (1981) and Adeniji (1996) who found radio as the second source of information after extension agents. The insignificant impact of Television and Pamphlets may be due to low income and low educational level of respondents.

TABLE 3: Sources of Information on Improved rice Varieties in Katcha Local Government area of Niger State

\begin{tabular}{lcc}
\hline Channel & Frequency & Percentage \\
\hline Radio & 56 & 56 \\
Extension Agents & 28 & 28 \\
Television & 10 & 10 \\
Pamphlets & 6 & 6 \\
\hline Total & $\mathbf{1 0 0}$ & $\mathbf{1 0 0}$ \\
\hline
\end{tabular}

\section{Reasons for Adoption}

In order to determine the relevance of the technology, reasons for adoption were asked. Table 4 depicts that $92 \%$ of the respondents adopted improved rice verities to obtain more yield and income, $21 \%$ adopted because it matures early, while $10 \%$ adopted in order to have long grain rice which is more marketable than short grain. The highest proportion of the respondents did so to obtain high yield and subsequently to have their income raised. This agrees with Clark and Akinbode (1968) who reported that financial gain and high yield are the apparent reason why farmers adopted recommended practices.

TABLE 4: Respondent's Reasons for Adoption

\begin{tabular}{lcc}
\hline Reasons for adoption & Frequency & Percentage \\
\hline To obtain more yield/income & 92 & 92 \\
Early maturity & 21 & 21 \\
Long grain (more marketable & 10 & 10 \\
\hline Total & $\mathbf{1 2 3}$ & $\mathbf{1 2 3}$ \\
\hline
\end{tabular}

*More than sample size due to multiple responses 


\section{Reason for Non-Adoption}

The reasons for non-adoption of improved rice verities is presented in Table 5.

All the respondents (100\%) reported that improved rice varieties are expensive coupled with the need to adopt other technologies that could enhance the yield of rice. Eighty six percent of the respondents complained that the improved varieties are not readily available.

TABLE 5: Respondent's Reasons for Non- Adoption of Improved Rice Varieties

\begin{tabular}{lll}
\hline Varieties & Frequency & Percentage \\
\hline Expensive & 22 & 100 \\
Not useful & 3 & 13.64 \\
Not readily available & 19 & 86.36 \\
Inadequate knowledge & 12 & 54.54 \\
Late information & 6 & 27.27 \\
\hline Total & $\mathbf{1 1 2}$ & $\mathbf{2 8 2}$ \\
\hline
\end{tabular}

*More than number of non adopters due to multiple respondents

\section{Costs and Returns To Rice Production}

Farm budgeting analysis, using the net farm income method was employed in the study. The profitability of any business can be deduced from the relationship between the costs incurred in running the farm business and the returns accruing to it (Adegeye and Dittoh, 1985). The result of the farm budgeting analysis (Table 6) revealed that the major components of the variable costs are cost of labour (55.42\%) and inputs (32.75\%). The high percentage of inputs could be attributed to the fact that majority of the farmers bought the inputs from the open market. This is similar to the observation made by Kudi (2000) in his study on costs and returns analysis of carrot production in two local government areas of Kaduna state. The study also revealed that fixed cost was very small (7.12\%). This is in agreement with the findings of Alamu et al (2000), Kudi (2000) and Sani et al (2003). The gross margin of the farm per hectares per production season stood at N84, 750.00, while the net farm income realized was found to be N80, 230.00. The average yield per hectare is 23 bags which is equivalent to $1,840 \mathrm{~kg}$. 
Journal of Agricultural Extension

Vol. 13 (1) June, 2009

TABLE 6: Average Cost and Returns Rice Production /Hectare (N) in Katcha Local Government Area, Niger State, 2007

\begin{tabular}{lll}
\hline Details & Average Value (A)/ha & Percentage \\
\hline Yield (kg) & $57,500.00$ & \\
Price ( $\mathrm{N} / \mathrm{kg})$ & 31.25 & \\
Gross income & 143.750 .00 & \\
Fixed Costs (FC) & & 0.79 \\
Depreciation on hand tools & 500.00 & 6.30 \\
Rent on Land (A /Season) & 4000.00 & 7.12 \\
Total Fixed Cost (TFC) & 4500.00 & 55.42 \\
Variable Cost (VC) & $35,200.00$ & 32.75 \\
Labour (family/hired) & $20,800.00$ & 4.72 \\
Inputs (seed fertilizer/agrochemical) $\mathbf{A}$ & 3000.00 & 92.88 \\
Other costs (transportation, storage) & $59,000.00$ & \\
Total Variable Cost (TVC) & 63,520 & \\
Total Cost(TC)=(TVC+TFC) & $84,750.00$ & \\
Gross margin (GI-TVC) & 80.230 .00 & \\
Net farm Income (GI-TC) & & \\
\hline
\end{tabular}

\section{CONCLUSION AND RECOMMENDATIONS}

The study shows that rice farmers are aware of improved rice varieties. The main sources of information were radio and extension agents. The major reasons for non-adoption of improved rice varieties are that they are expensive and non-availability of the input Therefore there is need for promotion of media and extension services to enhance the adoption of this technology.

\section{REFERENCES}

Adegeye, J. A., and Dittoh, J. S. (1985). Essentials of Agricultural Economics. Impacts Publishers Nigeria Limited, Ibadan, Nigeria Pp. 251.

Adeniji, O. B., Voh, J.P., Atala, T. K. and Ogungbile A. O., (2007). Adoption of Improved Cotton Production Technologies in Katsina State Nigeria. Journal of Applied Sciences 7(3) Pp. 397-401.

Adeniji, O.B, (1996). The Impact of Mass Media on Adoption of Agricultural Innovations in Kaduna State. Unpublished M.Sc. Thesis Department of Agricultural Economics and Rural Sociology. Ahamdu Bello University, Zaria. Pp 170

Akanya, E. E. (1990): Adoption of Recommended Horticultural Practices Among Small Scale Farmers In Rano Local Government Area of Kano State. Unpublished M.Sc, Thesis. Department of Agricultural Economics and Rural Sociology. Ahmadu Bello University Zaria.

Alamu, J.F, Coker, A.A.A. and Olukosi, J.O., (2000). Resource Use Efficiency in Tomato and Pepper Production among Fadama Farmers in Kaduna State. Nigeria Journal of Rural Economy and Society Vol. 1. Pp. 1-71. 
Chinaka, C.C, Ogbokiri, L. C. and Chinaka E. C. (2007). Adoption of Improved Agricultural Technologies by Farmers in Aba Agricultural Zone of Abia State. Proceedings of the $41^{\text {st }}$ conference of the Agricultural Society of Nigeria, IAR/ABU Zaria, Nigeria. Pp. 531-534.

Clark, R. C. and Akinbode, I.A. (1968). Factors Associated With Acceptance or NonAcceptance of Three Farm Practices In Western Nigeria. Research Bulletin No. I Department of Extension Education and Rural Sociology, University of Ife, Ile-Ife. N \& P.

D. F., Kenya Agricultural Research Institute (KARI), and International Maize and Wheat Improvement Centre (CIMMYT).

Idiong, I. C. (2005).Evaluation Of Technical, Allocative and Economic Efficiencies in Rice Production in Cross Rivers State. Nigeria. Unpublished Ph.D Dissertation Presented To The Department Of Agricultural Economics, Michael Okpara University Of Technology, Umudike, Nigeria.

Imolehin, E. D. and Wada, A. C.(2000). Meeting Rice Production and Consumption Demand of Nigeria with improved Technologies, International Rice Commission Newsletters: Vol.49 FAO , Rome

Jones, M. P. (1995). The Rice Plant and its Environment; West African Rice Development Association Training Guide 2. Pp 1-6

Kudi, T. M., (2000). Costs and Returns Analysis of Carrot Production in Two Local Government Areas of Kaduna State. Nigerian Journal of Rural Economy and Society 2, (1): 41-44.

NPC (2006) “2006"Population Census. National Population Commission Headquarters, Abuja

Olayide, SO. and Heady, E.O. (1982). Introduction to Agricultural Production Economics. University Press Ibadan, Nigeria Pp. 112.

Olukosi, J.O. And Erahbor, P.O. (1988) Introduction to Farm Management Economics (2nd Edition, AGITAB Publishers Zaria, Nigeria Pp.77

Sani, R.M., Kushwaha, S., Jirgi, A. J., and Umar B. Y. (2003). Economic Analysis of Small Scale Sorghum Production: A Study of Zuru Local Government Area, Kebbi State, Nigeria Journal of Science and Technology Research 2(1) 98-102.

Voh, J.P. (1981). Information Sources and Awareness of Selected Recommended Practices. A Study in a Village in Kaduna State, African Journal of Agricultural Science 8(112).

West African Rice Development Association (WARDA) (2003). Rice Trends in Sub-Saharan African: A Synthesis of Statistics on Rice Production, Trade and Consumption, UK, Sayce Publishing, Pp. 1-22.

www.agnet.org/library/bc/44002 